\title{
E-portfolios and English teacher education in Brazil
}

\section{Margaret Malia Spofford Xavier}

Professora Doutora do Departamento de Letras da UFOP - Universidade Federal de Ouro Preto; Ouro Preto; Minas Gerais; Brasil. malia_spofford@yahoo.com

Abstract: This article discusses the theory and implementation of a network of e-portfolios in the English as a Foreign Language (EFL) teaching practicum at a Brazilian public university. E-portfolios effectively motivate Brazilian student teachers to value the work produced during the teaching practicum, while contributing to the development of digital literacy and professional identity in a globalized world, in which English plays a key role. The use of the e-portfolio as a complement to traditional final reports constitutes a shift in episteme from isolated report to interconnected site, thus impacting student teachers' image of themselves and of EFL teaching.

Keywords: Brazilian English teacher education; e-portfolios; new literacies
Resumo: Este trabalho objetiva discutir a teoria e implementação de uma rede de e-portfolios nos estágios supervisionados de Língua Inglesa de uma universidade pública brasileira. Os e-portfolios valorizam as experiências e habilidades adquiridas durante o estágio supervisionado, enquanto contribuindo para 0 desenvolvimento de letramento digital e identidade profissional dos licenciandos, num mundo globalizado, no qual a Língua Inglesa desempenha um papel central. $\mathrm{O}$ uso do e-portfolio como complemento ao relatório final tradicional constitui uma mudança de episteme, de relatório isolado ao site interconectado, assim tendo um impacto na imagem dos estagiários deles mesmos, como futuros profissionais de ensino-aprendizagem de Língua Inglesa.

Palavras-chave: Formação inicial de professores de inglês; e-portfolios; novos letramentos 



\section{Introduction: cultivating dynamic spaces for English teacher education}

Theories of new literacies and multiliteracies (COPE; KALANTZIS, 2000, 2009; LANKSHEAR; KNOBEL, 2011) have been gaining vigor in language education since the formation of the New London Group in the 1990s. These new concepts of literacy, learning, and teaching, including digital technologies, are changing approaches and expectations for the teaching of languages in Brazil, as reflected in recent official policy documents, such as the Curricular Guidelines for High School- Foreign Languages (Orientações Curriculares para o Ensino Médio - Língua Estrangeira: OCEM-LE) (BRASIL, 2006) on the national level, and, on a regional level, the Basic Curricular Content for Minas Gerais (Conteúdo Básico Comum - Minas Gerais) (DIAS, 2006). These changes in policy for basic education imply the need to re-evaluate approaches to language teacher education at the university level. As the amount of available information and degree of interconnectivity increases at an exponential rate and the concept of globalization becomes banal for those included in these processes, special challenges arise for traditional models of teacher education and well as classroom practice. For example, digital literacy has become a necessary skill for most classroom teachers, who may also find their role destabilized or called into question. The appearance of a "new globalized and technologized citizen" who can "enact different forms of citizenship" (MATTOS, 2011) also implies new roles for the teachers of this citizen (EDWARDS; USHER, 2008; RIZVI; LINGARD, 2009; KUMARAVADIVELU, 2012).

At the same time, even though English is acquiring greater currency as Lingua Franca or the global language of Internet and business transactions, one still observes significant difficulties in the attainment of 
foreign language proficiency among pre-service English teachers in Brazil, and consequently, among children and adolescents learning English in basic education. This is not to mention the structural problems associated with curriculum and organization for language teaching in public schools, as well as insufficient pay for teachers, who need to be recognized as key figures in Brazil's future economic growth and, more importantly, in the well being and global-local citizenship of the country's youth. In our English teacher education program at a federal university in the interior of Minas Gerais state, we aim to create efficient teaching and learning solutions that can effectively grapple with these challenges - professional identity, language proficiency, and digital literacy - in a dynamic scenario of global-local interactivity. The e-portfolios project, which I will describe in this article, is one of the proposed solutions that we have begun to implement.

Our research and experience in designing an e-portfolio network suggests that this format may be of special interest to English teacher certification programs in Brazil. This tool provides incentive towards digital literacy as well as an active forum for the critical examination of the role of new literacies in professional identity and practice, always already imbedded in the network exemplifying global-local interactivity, the language of which is predominantly English, serving as an added benefit for student teachers of this language. E-portfolios also stimulate reflection and collaboration, key facets of professional development. While e-portfolios, also called "webfolios" or "digital portfolios," are used sporadically in Brazil, they are not yet widely implemented at the institutional level or considered common practice in teacher education curriculum. Some recent articles do indicate the growth of their use in fields such as Nursing and Medicine and pre-service 
mathematics teacher education (BAIRRAL, SANTOS 2012), confirming the need for further examination and debate about this teacher education tool in Brazil.

This article discusses, from the perspective of Applied Linguistics, the e-portfolio project implemented at a Brazilian English teacher certification program beginning in 2012. A theoretical discussion of e-portfolio use in teacher education will be followed by an explanation of the original system implemented, questionnaire and interview results, offering approaches to practical challenges based on local context but applicable broadly. While the e-portfolio has been a positive addition to the language teacher education curriculum at our university, certain aspects of digital infrastructure, in particular, have limited implementation in this initial phase. Suggestions for future development across educational contexts are indicated.

\section{Context and Theoretical Framework}

One major requirement of the English teaching curriculum is the supervised teaching practicum (estágio supervisionado), mandated 400 total hours by law, and currently 420 hours at our university, divided into four semesters. Traditionally, each semester, the student teacher (estagiário) is required to submit a final report, as established by Law № 11.788 of 25 September 2008 (which applies to all types of professional internships). The final report submitted by student teachers of English at our institution has traditionally been a spiral-bound, printed portfolio (relatório final, also known as pasta de estágio), with all relevant writing, documentation, and materials, such as lesson plans, produced during the practicum period. These materials are also submitted on CD-ROM. After assessing the final report's functionality during three academic semesters, a revision seemed urgent. While serving the legal 
and bureaucratic requirement for all forms of professional internships in Brazil, the report's typical format tends to be repetitive across consecutive semesters and limited in terms of generation of knowledge (SILVA, 2013). Furthermore, its value for teacher development (rather than for bureaucratic purposes) was marginalized by earlier curricular problems, such as a lack of sequence between each semester of practicum. E-portfolios were first conceived in this context as a possible interface or partial alternative to the final report of the teaching practicum.

Concomitantly, an "archaeological" examination of the archive of student teacher final reports revealed stacks of forgotten voices and experiences, accumulated over a period of five years. The binders are stored in the arquivo morto, literally translated as the "dead" archives, since few have ready access to them in that dimly-lit attic space. In their current form, these extensive collections of knowledge-making and personal transformations remain disconnected from the possibility of any greater impact and positive repercussions on professional development: publication, presentation, or some other form of interactive testimony. Michel Foucault's (1972) explorations of the concepts of archive and archeology suggest, for our purposes, that the discursive traces present in the practices of documenting teaching experiences inform the conditions of possibility for knowledge in a given time and place, that is, they constitute, in part, the episteme of English student teachers, as they construct a theoretically-based teaching practice in a diverse range of locales. The "scientific" product of the supervised teaching practicum, as such, impacts what it means to be/become a teacher of English in Brazil, shaping preservice teacher epistemological beliefs (BROWNLEE, 2001). If we consider, however, that the destination of the student teacher final report is the arquivo morto within weeks of its being written, this suggests something 
about the value of knowledge generated as well as the image of such knowledge in the subjective perception of the student teacher. Alternative practices of teacher education on a global scale show that final reports in other formats, particularly digital, may go beyond bureaucracy or isolated analysis to serve as dynamic and collaborative spaces for the creation of both knowledge and the development of a critical teaching practice. In brief, these practices seek both to mine and to revive the archive. The e-portfolio, widely used throughout the United States across a range of teacher certification programs, provides just such a dynamic space. An e-portfolio is a learning and assessment tool, usually in the form of a website, featuring a "digitized collection of artifacts including demonstrations, resources, and accomplishments that represent an individual, group, or institution" (LORENZO; ITTELSON, 2005). In addition, it serves as an administrative tool to organize and manage work, a forum for the exchange of ideas and feedback, and a space for personal reflection and growth (p.2).

Interactivity and collaborative networks, essential features of the new literacies and hence their epistemologies, also serve as ways to strengthen language teacher development (LANKSHEAR, 2010). Various alternatives for teacher development can be negotiated and imagined through the collaboration and connections created between pre-service and in-service teachers, between student teachers within the same university or in different institutions, in addition to the important and complex partnership between schools and the universitybased teacher education programs. The perspectives afforded by new literacies create opportunities for preservice teachers to engage in critical reflection about diverse meanings of collaboration and interaction in the educational process - the local and the global; inclusive, heterogeneous classrooms; new media and technologies- 
all contributing towards the renewal of university-based teacher education and language teaching in basic schooling (REICHMANN, 2012; MATEUS, 2013). Internetbased websites' visibility and openness to feedback and opportunities for exchange and collaboration suggest that the skill of using and making websites in education is an essential aspect of educating Brazilian teachers, even as digital inclusion remains problematic in many regions of the country (BUZATO, 2008).

Silva et. al. (2011) underscore that the portfolio is an ideal format for assessing student teacher learning as well as stimulating professional development, among a range of other functions (p. 529). They note the flexibility and personalization of the portfolio as beneficial to teacher education, as well as the versatility of the portfolio's eventual roles: from teacher preparation and evaluation to self-presentation on the job market (p. 532533). In short, the e-portfolio is a multi-dimensional tool, the digitalization of which only enhances its dynamic nature, efficiency, visibility and collaborative potential for student teachers (p. 537-538). The authors highlight the potential of the portfolio to "mirror" individual and group progress; as we will see, the proposal of this e-portfolio project is that student teachers will revise their e-portfolios each semester of the supervised teaching practicum to reflect their personal and professional growth in both synthetic and analytic movements. The e-portfolios serves as a concrete practice towards critical, reflexive teaching and teacher education (p. 538), as well as professional re-positioning - moving from the role of student to the role of teacher and pedagogical thinking (MATEUS et al, 2002).

Vieira and Sordi (2012) offer a recent perspective on the uses and limits of portfolio work for both learning and assessment at the university level in Brazil. Their interest in the portfolio format is imbedded in their 
commitment, as educators, to transform their own pedagogical practice in dialogue with the other and in search of new ways of being, doing, co-existing, and knowing (p. 3). The process-based nature of portfolio work, with its possibility for intentional and progressive learning and evaluation, balances personal and affective factors with learning, perhaps a better fit for Brazil's diverse educational landscape and the complexities inherent to evaluation of learning (VIEIRA, SORDI 2012, p.5).

This personalized, flexible process of learning and evaluation afforded by portfolios - and energized by digitalization - offers important benefits to English language student teachers. If academic content areas can be complex and inscrutable, or difficult to articulate (GEE, 2008, p. 200), so is the experience of teaching, as Richards and Lockhart (1996) point out: teachers are often unaware of what is happening as they teach (p. 3). In the words of Gee,

Here we reach a central paradox of all deep learning. It won't work to try and tell newcomers everything. We don't know how to put it all into words, because a domain of knowledge is first and foremost made up of ways of doing, being, and seeing, ways complex enough that they outrun our abilities to put them all into explicit formulations (2008, p. 201).

For teacher education, the way we transmit this domain, this "doing, being, and seeing", is always already a product of local culture, practices, and pressures, in dialog with research and theory. Kumaravadivelu's (2012) proposal for language teacher education on a global scale considers this knowledge, broadly construed, along the axes of "global perspectives" (postnational, postmodern, postcolonial, post-transmission, postmethod) and “operating principles" (particularity, practicality and 
possibility). In this framework, teacher education programs would seek to develop practicing teachers who value their local contexts and own classroom practices, while seeing themselves as producers, strategists, researchers and "transformative intellectuals" in a fast changing global society. The pre-service teacher learns to see what happens in the classroom and "learn to interrogate their teaching Self using critical autoethnography as an investigative tool, and to draw a self-portrait connecting the personal, the professional, the pedagogical, and the political." (my emphasis, 2011: ebook locations 216-218). We return, here, to the idea of the portfolio as mirror, inserted as e-portfolio into a dynamic global network of potential collaborators that also serves as scaffolding for continued language learning.

As Vieira and Sordi (2012) emphasize, the use of portfolios requires "planning, theoretical foundations, and the preparation of both students and teachers" (p.18). This preparation involves shifting attitudes prevalent in Brazil about the "continuous, unfinished, relational, and dialogic process" of the teacher-student relationship and how learning can be evaluated and/or assessed without it becoming a bureaucratic process (ibid, p. 20). In the supervised teaching practicum, as we will see in the following sections, time is certainly an issue for the creation of the e-portfolio, given the total credit hours is, by law, 400, divided in our institution over four semesters. Integration of the portfolio into the actual student teaching experience is of the essence; otherwise, it could become another burdensome bureaucratic requirement, as discussed above.

Helen Barrett's comprehensive studies on e-portfolios offer many resources for both secondary schools and teacher education programs. She emphasizes the power of modern digital technology as a tool to capture the learning moment, to support 
reflection and metacognition. The e-portfolio is versatile, as a multimedia, digital repository, showcase, and workspace, and requires a balance between the "showcase" or product function of the e-portfolio and the learning and reflection function of the e-portfolio (BARRETT, 2010, p. 7). The reflective aspect of e-portfolios stimulates integrated, experiential learning, the conceptualizing and construction of meaning. The reflective aspect of the e-portfolio leads to greater self-awareness and a sense of ownership over one's accomplishments and emerging professional identity, building a "digital story of deep learning" (BARRETT, 2010, p. 6). In addition, the e-portfolio helps to build a "positive online identity" that may someday replace traditional CVs. Barrett also points out how the prevalence of cell phones allows for the capture of the learning moment, a "contemporaneous record" through audio and video recordings, text or email to blog.

The e-portfolio's insertion into a variety of networks-departmental, university-wide, regional, national, and international - lead to the creation of relationships and a sense of accountability, which on the international level, help in the development of intercultural or "global competence" in our future teachers (ZHAO, 2010). It should be noted, however, that there are no specific national policies recommending or orienting the use of e-portfolios, as is the case in the United States and in some European countries, although the Brazil's National Education Plan - Plano Nacional de Educação (PNE) (7.7) mentions the use of educational technology as a strategy to improve learning outcomes in basic education. For higher education, goals 15 and 16 of the PNE, which indicate that teachers should possess specific training for their area and that $50 \%$ will have some level of graduate degree, would be directly supported by the systematic implementation of teaching e-portfolios. 
In summary, the potential benefits for teacher education programs, particularly in English, are as follows. First, e-portfolios make the teacher education experience more dynamic, instilling the values of collaboration and global-local networking into teaching practices and professional image. As the $21^{\text {st }}$ century progresses, the teaching profession and academic knowledge become increasingly "open-access" and these demands must be incorporated into teacher education programs. Second, e-portfolios provide Brazilian English teachers an important opportunity for digital literacy training integrated with critical, reflective professional growth. Third, English teaching in basic education may improve because of increased digital fluency, teacher cooperation, increased contact with the target language, as well as imbedded reflective practices (PINHO, LIMA 2013). At the same time, student teachers learn a powerful digital skill - website creation and maintenance- for their classroom-based careers. E-portfolios are a teaching and learning resource with enormous potential for English in Brazilian basic education, in the form of language portfolios (as seen more commonly in Europe) or as a means of organizing alternative and project-based assessments.

\section{2 e-portfolios@UFOP: Methodology}

In this context and theoretical framework, we designed the project “e-portfolios@UFOP: Developing Professional Identity in the English Supervised Teaching Practicum." It received support in the form of an undergraduate student scholarship assistant funded through the Pró-reitoria de Graduação's PróAtiva program, which aims to improve undergraduate education and pedagogical strategies. The project's primary objectives were to create structure for student teacher development in terms of professional identity, 
while also contributing towards digital literacy and global citizenship. It was also considered an attractive point to provide graduating students with a modern and concrete means to represent themselves online, thus facilitating their entry into some sectors of employment. The first phase of the e-portfolio network was implemented in the first semester of 2012, in two groups of English student teachers enrolled in the middle school (Ensino Fundamental II) teaching practicum courses, both observation and student teaching. Eighteen students were involved in the project. By initially elaborating e-portfolios with students enrolled in the first two teaching practicum courses, the project foresaw that the student teachers would continue to revise their e-portfolios each semester, allowing the process of teacher development and reflection to occur over a period of 1.5 to two years.

The first step in implementing the project involved the creation of a list of criteria necessary for the development of the e-portfolio network, based on the learning objectives for student teachers. We also decided on network architecture. Student teachers would be able to keep their e-portfolios password protected from the general public, but other student teachers (along with supervising teachers and professors) needed have access to facilitate collaborative learning and the fostering of relationships. The website platform had to be easily accessible, free, and available in Portuguese and English. Ideally, it would be a university network with accounts generated on demand, but this was not immediately available. Because of studies reporting difficulties of digital literacy and inclusion in Brazil, as well as the instability of the university network at the time, we also decided that the e-portfolio would not replace the Final Report but serve as a complement, where some important texts developed in the weekly Reflective Seminar would be shared, such as Teaching Philosophy, Language Learner's 
Biography, Interesting Links for Language Teaching, and Classroom Management Plan. The project was explained with an informative handout and discussion session at the beginning of the semester, and computer lab sessions were scheduled in the syllabus. The e-portfolio was a required activity worth $5 \%$ of the final grade. After a period of research regarding the most efficient platform to use for the project, based largely on ease of use, we initially selected Blogger ${ }^{\mathrm{TM}}$, a Google $\mathrm{TM}^{\mathrm{TM}}$-integrated website design tool. In 2013 we added $\mathrm{Wix}^{\mathrm{TM}}$ as an alternative platform, facilitating the design component of portfolio development.

In mid-2012, the project's homepage was created, along with the basic network structure. The student assistant created student teacher accounts and sites ahead of the class sessions, with a common password that could later be personalized. All sites added the main account as a reader, with a common password. Even if kept private, the e-portfolio would be accessible to anyone with this username and password, which was provided to all members of the class. While we realized that this involved a slight security risk, we had inadequate technical support (particularly in the form of programming and a server) to create a private network in another manner. Wix ${ }^{\mathrm{TM}}$ sites allow for specific page password protection that can be shared without the need for a Google ${ }^{\mathrm{TM}}$ account, a major advantage of this platform. An e-portfolio-specific platform, such as Digication ${ }^{\mathrm{TM}}$ in Google Apps for Education ${ }^{\mathrm{TM}}$, would be a much better option, but this requires institutional-level adherence and technical support.

With their sites created and personalized, student teachers were asked to compile their reflective texts and artifacts from the teaching practicum, such as lesson plans, photos, and activities and store them either online (in a service such as Dropbox ${ }^{\mathrm{TM}}$ or Google Drive ${ }^{\mathrm{TM}}$ ) or 
on a USB drive. At this point, the university computer lab was reserved and used for the first class session, in which the first personalized versions of the e-portfolios would be elaborated and students' questions and difficulties resolved. A projector was set up to show the steps involved in creating an e-portfolio. In addition, instructions, both written and in video, were available on the project's homepage. After the initial training session, additional sessions were scheduled throughout the semester to allow for e-portfolio building. Student research assistants also worked with student teachers individually upon request.

Each semester, student teachers revised their e-portfolios. In 2013, the Language Lab, a space better equipped for instructional purposes, became internetconnected and we transferred our classes there. In the second semester of 2013, the project was also expanded to include the teacher education programs in Portuguese, reaching a much larger number of students. Also in 2013, with the expansion of the project, we no longer pre-created student teacher accounts because of time and software constraints. Instead, the creation of the e-portfolios was performed according to a set pattern in the first e-portfolio class, ensuring standard address format, privacy settings, and added readers or page passwords (if desired by the student teacher) for networking, depending on the chosen platform.

\section{Project Results and Analysis}

The project was evaluated qualitatively at the end of the first semester of each year (2012 and 2013) through semi-structured interviews and anonymous questionnaires in which the participants gave voluntary informed consent (see Appendix A). These results have been overwhelmingly positive in terms of the 
impact on student teachers' perception of their work. These perceptions demonstrate the potential for longterm improvement of the teacher education program, as most students see instruction in and through digital technologies as a key point in their pre-service education. All students surveyed wished to continue developing their e-portfolios in future semesters and demonstrated a high level of enthusiasm about its promise. In a question asking how this project has affected their professional identity as future teachers (Appendix A, question 7), the most popular response (89\%) was "The e-portfolio served as a resource to recognize and publicize my professional work," followed by "Through the e-portfolio, I can imagine myself as a professional on the job market" (67\%). One student response to question 5 showed the importance of this opportunity for those with little computing experience: "At the beginning, I had a hard time, because I don't like to do things on the computer, but afterwards I figured it out and published my site. It wasn't so hard." Of those surveyed and interviewed, the chance to create websites, with the varied skill development this entailed, was universally considered positive. One student, who worked on her e-portfolio over two semesters before graduating, achieved excellent results. Her site, which is public and available through our homepage, included several pages: About Me, Teaching Credo, Lesson Plans, Worksheets, Interesting Links, Interesting Videos, Useful Images, English is Fun!, Prezi, Multiletramentos, Games, and Contato. In addition, during her teaching practicum she developed several lessons for student teaching which aimed to stimulate school students to think about the connections between English, social media, and digital technology. The overall reaction to the project is well summarized by one of the student teachers who participated in the anonymous questionnaire aimed at evaluating the project: 
By means of the e-portfolio, it was possible to publicize and share my work with other student teachers, as well as with whomever else might be interested. The site also offers opportunities to create partnerships with other people in my area of study. As a future teacher, I believe that such a tool as this will be extremely useful for my profession, since teachers and researchers need to be present in the virtual context as well. In sum, the e-portfolio has much to contribute to our academic and professional lives.

It should be noted that the majority of student teachers did not develop their e-portfolios as fully as hoped in this first phase, most likely because the primary tool of evaluation in the course was not the complementary e-portfolio, but the final report. There was also concern about imposing a new tool on students from above, especially one that might also seem alienating or difficult to some students. It was judged that a gradual introduction of the tool would be more effective for the long-term success of the project. In addition, for most students, time was a factor in completing the e-portfolios, given the limitations of the post-strike academic calendar and the practical demands of the teaching practicum. Providing the necessary faculty training for other teacher practicum professors was also challenging in terms of time and resources, since some lacked prior experience with website creation. As such, we consider centralized technical support as essential to implementing and maintaining a successful e-portfolio network. Holding training sessions for student teachers, and including their professors in the sessions, is more effective than training professors separately and asking them to later train their student teachers, unassisted. Further, at some institutions, such support might be able to be offered across all teacher education programs. However, for us, like for Bairral and Santos (2012), the "published 
portfolio (the product) is not as important in itself as the process of constructing and reconstructing it" (p. 2), as well as the process of gaining digital fluency, however gradual. In the second semester of 2013, some professors in the teacher education program in Portuguese allowed the e-portfolio to replace the Final Report, requiring students to print out screen shots of their sites and bind it together with legal documentation, but these results are not yet available for evaluation. Some examples of successful student e-portfolios are available through the project homepage.

\section{Final Considerations}

The design and implementation of e-portfolio networks, where basic Internet and computing resources are available, can be effectively integrated into existing English teaching practicum programs in Brazil, conferring multiple benefits on student teachers, including their participation in a dynamic collaborative network, increased digital fluency, and heightened critical awareness of English language study as related to new literacies. The promotion of the technological, conceptual, and communicative dimensions by e-portfolios results in the "capacity to integrate different areas of $[\ldots]$ curriculum and the emergence of different concepts, thinking, and sharing experiences" (BAIRRAL, SANTOS, 2012, p. 6). I will conclude with some broad concerns for e-portfolio networks in university contexts. Lorenzo and Ittelson (2006) offer several important points that must be considered carefully regarding the logistics of e-portfolio networks, for anyone contemplating their use. These considerations will vary across regional and institutional cultures, and will depend on institutional organization and information technology resources. According to the authors, some of these "issues and challenges" include: 
- Should an e-portfolio be an official record of a student's work?

- How long should an e-portfolio remain at an institution after the student graduates?

- Who owns the e-portfolio?

- How are e-portfolios evaluated in a manner that is both valid and reliable?

- How can institutions encourage critical reflection in the design and use of e-portfolios? (p. 3-4)

Other issues noted by Lorenzo and Ittelson (p.5) in teaching e-portfolios include:

- Information overload

- Technological training of faculty

- Copyright and privacy issues

- Encouraging adoption of e-portfolios

Furthermore they cite hardware and software, support and scalability, security and privacy, and longterm maintenance as serious challenges facing successful implementation of these systems (LORENZO, ITTELSON, p.3-9). Network upkeep and architecture in the long term may be problematic given current working conditions in some Brazilian universities. Nevertheless, the benefits of introducing e-portfolios into our program have been manifold and it is a valuable initiative to undertake, when integrated into a critical-reflective teacher education program. As Battacharya and Harnett (2008) state, "without a central focus on reflection, e-portfolios are in danger of becoming simply a collection of information rather than a mechanism for the development of meaningful knowledge" (p. 19). In the context of Brazilian English 
teacher education, part of that "meaningful knowledge" is an invigorated sense of the profession and its positive possibilities, and the dynamicity of meaning-making itself, revived through digital technology and participation in local-global dialogue. 


\section{References}

BAIRRAL, M. A.; DOS SANTOS, R.T. E-Portfolio improving learning in mathematics pre-service teacher. In: Digital Education Review, n. 21, p.1-12, June 2012. Available at: <http://greav.ub.edu/der/1>. Access on: 10 January 2014.

BARRETT, H. Balancing the Two Faces of ePortfolios. In: Educação, Formação \& Tecnologias, 3(1), p. 6-14, 2010. Available at: $<$ http://eft.educom.pt $>$. Access on: 10 December 2013.

BATTACHARYA, M.; HARTNETT, M. E-portfolio Assessment in Higher Education. In: 37th ASEE/IEEE Frontiers in Education Conference Proceedings, 2007.

BRASIL. Orientações Curriculares para o Ensino Médio. Linguagens, Códigos e suas Tecnologias. Conhecimento de Línguas Estrangeiras. Brasília: Secretaria da Educação Básica, 2006.

. Plano Nacional de Educação. 2010. Available at: <http://portal.mec.gov.br/index.php?option=com content\&id=16478\&Itemid=1107>. Access on: 08 February 2014.

BROWNLEE, J. Epistemological Beliefs in Pre-Service Teacher Education Students. In: Higher Education Research \& Development, v. 20, n. 3, p. 281-291, 2001.

BUZATO, M. E. Inclusão digital como invenção do quotidiano: um estudo de caso. In: Revista Brasileira de Educação, v. 13, n. 38, p. 321-342, maio/ago. 2008

COPE, B.; KALANTZIS, M. Multiliteracies: literacy learning and the design of social futures. London: Routledge, 2000.

."Multiliteracies": New literacies, new learning. In:

Pedagogies: an International Journal, 4(3), p. 164-195, 2009. 
DIAS, R. Conteúdos Básicos Comuns Língua Estrangeira: Ensino Fundamental e Médio: Proposta Curricular. Secretaria de Estado de Educação de Minas Gerais: Belo Horizonte, 2006. Available at: <http://www.educacao.mg.gov.br/site. $>$ Access on: 30 June 2014.

EDWARDS, R.; USHER, R. Globalisation and Pedagogy: Space, Place and Identity. London: Routledge, 2008

GEE, J. Game-Like Learning: An Example of Situated Learning and Implications for Opportunity to Learn. 2008. Available at: <http://www.jamespaulgee.com/node/29>. Access on: 15 January 2014.

HANNON, V.; PATTON, A.;TEMPERLEY, J. Developing an Innovation Ecosystem for Education. White Paper. Cisco, Innovation Unit, 2011.

KUMARAVADIVELU, B. Language Teacher Education for a Global Society: A Modular Model for Knowing, Analyzing, Recognizing, Doing, and Seeing. Routledge, 2012.

LANKSHEAR, C. 'The Challenge of Digital Epistemologies'. In: Education, communication \& Information. London: Routledge, 2010.

LANKSHEAR, C.; KNOBEL, M. New literacies: changing knowledge and classroom learning. Buckingham: Open University Press, 2011. 3rd edition.

LORENZO, G. \& ITTLESON, J. An Overview of E-portfolios. Ed. Diana Oblinger. Educause Learning Initiative. Paper 1, 2005.

MATEUS, E.F.; GIMENEZ, T.N.; ORTENZI, D.I.G.B; REIS, S. A prática do ensino de inglês: desenvolvimento de competências ou legitimação de crenças? In: Revista Brasileira de Linguística Aplicada, v.2, n. 1, p. 43-59, 2002.

MATEUS, E. Práticas de formação colaborativa de professores/ as de inglês: representações de uma experiência no Pibid. In: Revista Brasileira de Linguística Aplicada, v. 13, n. 4. p.11061130, 2013. 
MATTOS, A. M. A. O Ensino de Inglês como Língua Estrangeira na Escola Pública: Novos Letramentos, Globalização e Cidadania. 2011. 248 f. (Doutorado) Programa de Pós-Graduação em Estudos Linguísticos e Literários em Inglês, Faculdade de Filosofia, Letras e Ciências Humanas, Universidade de São Paulo, São Paulo, 2011.

PINHO, I.; LIMA, M. Teacher's digital fluency: a new competence for foreign language teaching. In: Revista Brasileira de Linguística Aplicada, vol.13, n.3, p. 711-73, 2013.

REICHMANN, C.L. Práticas de letramento docente no estágio supervisionado de letras estrangeiras. In: Revista Brasileira de Linguística Aplicada, Belo Horizonte, v. 12, n. 4, p. 933-954, 2012.

RICHARD, J.; LOCKHART, C. Reflective Teaching in Second Language Classrooms. Cambridge University Press, 1996.

RIZVI, F.; LINGARD, B. Globalizing Education Policy. London: Routledge, 2009.

SILVA, J.; REBELO, N.; MENDES, P.; CANDEIS, A. O portefólio na formação e avaliação profissional de professores. In: Educação e Pesquisa, São Paulo, v.37, n.3, p. 529-548, set./ dez. 2011.

SILVA, W. Escrita do gênero relatório de estágio supervisionado na formação inicial do professor brasileiro. In: Revista Brasileira de Linguística Aplicada, Belo Horizonte, v.13, n.1 jan./mar. 2013.

VIEIRA, M.L.; SORDI, M.R.L. Possibilidades e limites do uso do portfolio no trabalho pedagógico no ensino superior. In: Revista e-curriculum, São Paulo, v.8, n.1, abril 2012 Available at: <http://revistas.pucsp.br/index.php/curriculum.> Access on: 13 December 2013.

ZHAO, Y. Preparing Globally Competent Teachers: A New Imperative for Teacher Education. In: Journal of Teacher Education, v. 61, n. 5, p. 422-43, nov/dec 2010. 


\section{Acknowledgements:}

I would like to thank the Pró-reitoria de Graduação for their support during 2012 and 2013 with the Pró-Ativa scholarship program. My student assistants Evandro Souza, Viviane de Andrade Soares, and Patrícia Lage were essential in carrying out the project. I would like to acknowledge, as well, the collaboration of my departmental colleagues in expanding the e-portfolio program to the teacher certification program in Portuguese.

\section{Appendix A: E-portfolio survey (conducted through Survey Monkey ${ }^{\mathrm{TM}}$ in Portuguese)}

1. No geral ficou satisfeito com o projeto, nem satisfeito nem insatisfeito, ou insatisfeito? (In general, were you satisfied, neither satisfied nor dissatisfied, or dissatisfied with the project?)

2. Quantas questões foram resolvidas pelas instruções e/ou monitor do projeto? (Were your questions and concerns resolved by the instructions and/or project assistant?)

3. Qual é a probabilidade de continuar o uso do e-portfolio? (How likely are you to continue using your e-portfolio?)

4. Na sua opinião, seria melhor hospedar os e-portfolios nos sites da UFOP ou continuar com um serviço grátis, tipo Blogger, Weebly, ou Wordpress? (In your opinion, would it be better to host the e-portfolios through UFOP or to continue with a free service such as Blogger, Weebly, or Wordpress?)

5. Descreva sua primeira experiência com o e-portfolio. (Describe your first experience with the e-portfolio.)

6. Com que frequência as preocupações com a privacidade evitam que coloque alguma informação no e-portfolio? (How often did concerns about privacy impede you 
from including something in your e-portfolio?)

7. De que forma esse projeto afetou sua identidade profissional como futuro docente? Escolhe todas as respostas com as quais você concorda. (In which ways did this project affect your professional identity as a future teacher? Choose all answers which apply.)

- O e-portfolio me estimulou a ser mais crítico e reflexivo (The e-portfolio encouraged me to be more critical and reflective)

- O e-portfolio é um trabalho mais no semestre e acrescentou pouco a minha formação (The e-portfolio is just another task during the semester and added little value to my education).

- O site do e-portfolio me ofereceu um recurso para reconhecer e divulgar meu trabalho como profissional (The e-portfolio offered me a way to recognize and promote my work as a professional)

- Prefiro não usar as novas tecnologias na minha atuação como docente; sou mais tradicional ( $I$ prefer not to use digital technologies in my work as a teacher)

- Atravês do e-portfolio, consigo me imaginar como profissional no mercado de trabalho (Through the e-portfolio, I can imagine myself as a professional on the job market)

- O e-portfolio não afetou minha identidade profissional (The e-portfolio did not impact my professional identity)

- A oportunidade de colaboração com colegas de trabalho é importante para minha carreira (The opportunity to collaborate with colleagues is important for my career)

- O e-portfolio valoriza meus estudos e trabalho (The e-portfolio contributes value to my studies and work) 
1. Ter a oportunidade de ler os e-portfolios de outros colegas foi... (Having the opportunity to read my colleagues' e-portfolios was...)

2. Quais são as suas recomendações para melhorarmos o nosso projeto? (What are your recommendations to help improve our project?)

3. Em futuros semestres, o uso do e-portfolio no estágio supervisionado deve ser maior? Menor? Ou igual? (In future semesters, should the e-portfolio be used more, less, or the same amount in the teaching practicum?)

Recebido em 28/02/2014

Aceito para publicação em 21/07/2014 